\title{
Pengelompokan Dampak Gempa Bumi dan Kerusakan Pada Wilayah Berpotensi Gempa di Provinsi Sumatera Barat
}

\author{
Ipin Sugiyarto ${ }^{1, *}$, Rama Irawan ${ }^{2}$, Didi Rosiyadi ${ }^{2}$ \\ * Korespondensi: e-mail: ipin.sugiyarto@gmail.com
}

\begin{abstract}
${ }^{1}$ Sistem Informasi; Universitas Nusa Mandiri; Jl. Raya Jatiwaringin No.2, RW.13, Cipinang Melayu, Kec. Makasar, Kota Jakarta Timur, telp (021) 8462039 dari Universitas Nusa Mandiri; e-mail: ipin.sugiyarto@gmail.com

2 IImu Komputer; Universitas Nusa Mandiri; JI. Raya Jatiwaringin No.2, RW.13, Cipinang Melayu, Kec. Makasar, Kota Jakarta Timur, telp (021) 8462039 dari Universitas Nusa Mandiri; e-mail: ramairawan033@gmail.com, didi.rosiyadi@lipi.go.id
\end{abstract}

$\begin{array}{ll}\text { Submitted } & : 29 \text { September } 20 \\ \text { Revised } & : 28 \text { Oktober } 2021 \\ \text { Accepted } & : 15 \text { November } 2021 \\ \text { Published } & : 30 \text { November } 2021\end{array}$

\begin{abstract}
Earthquake disaster data represent knowledge from the West Sumatra Province, data taken from the official website of the National Disaster Management Agency that occurred in the period 2001 to 2018. Clustering data mining techniques are used to determine the earthquake impact area using Knowledge Discovery Data. Mining Method (KDD) consisting of Domain Understanding, Additional Selection (Data Selection), Preprocessing (Data Cleaning, Data Sampling), Transformation (Data Normalization), Data Mining (K-means \& Linear Regression), Evaluation and Interpretation (cluster \& Prediction). The results showed that the use of the $K$ Means method resulted in 3 clusters with the largest earthquake impact in the city of Padang in 2009, while the use of Linear Regression estimates the impact of victims and damage to facilities and units that often occur in earthquake locations. The purpose of the research is to implement and categorize and predict to find out the results of the impact and damage of the earthquake that occurred in the province of West Sumatra.
\end{abstract}

Keywords: Clustering, Data Mining, Earthquakes, KMeans, Linear Regression.

\section{Abstrak}

Data bencana gempa bumi mewakili pengetahuan dari wilayah Provinsi Sumatera Barat, data diambil dari situs resmi Badan Nasional Penanggulangan Bencana yang terjadi pada periode 2001 hingga 2018. Teknik penambangan data klastering digunakan untuk menentukan daerah dampak gempa menggunakan Pengetahuan Discovery Data. Metode Penambangan (KDD) yang terdiri dari Pemahaman Domain, Seleksi tambahan (Seleksi Data), Preprocesing (Pembersihan Data, Pengambilan Sampel Data), Transformasi (Normalisasi Data), Penambangan Data (K-means \& Linear Regresi), Evaluasi dan Interpretasi (klaster \& Prediksi). Hasil penelitian membuktikan bahwa penggunaan metode K-Means menghasilkan 3 klaster dengan dampak gempa paling besar di kota Padang pada tahun 2009, sedangkan penggunaan Liniear Regresi memperkirakan dampak korban dan kerusakan pada fasilitas dan unit yang sering terjadi di lokasi gempa. Tujuan penelitian mengimplementasikan dan mengkategorikan dan memprediksi untuk mengetahui hasil dampak dan kerusakan gempa yang terjadi di provinsi Sumatera Barat.

Kata kunci: Data mining, Gempa Bumi, Klastering, KMeans, Linier Regresi. 


\section{Pendahuluan}

Data mining merupakan kegiatan yang meliputi pengumpulan, pemakaian dari serangkaian proses untuk mendapatkan informasi yang berguna dalam menemukan keteraturan (Pramudiono, 2006). Data mining juga dapat diartikan sebagai serangkaian proses untuk mendapatkan informasi yang berguna. Kegunaan Data mining adalah untuk menspesifikasikan sebuah pola yangharus ditemukan dalam proses Data mining. Dalam Data mining terdapat banyak Teknik dalam pengerjaannya, diantara algoritma yang dipakai dalam Data mining yaitu algoritma naïve bayes, decision tree, jaringan saraf tiruan dan masih banyak lainnya (Davies, 2004).

Nama Provinsi Sumatera Barat bermula pada zaman (VOC), di mana sebutan wilayah untuk kawasan pesisir barat Sumatera adalah Hoofdcomptoir van Sumatra's westkust. Kemudian dengan semakin menguatnya pengaruh politik dan ekonomi VOC, sampai abad ke 18 wilayah administratif ini telah mencangkup kawasan pantai barat Sumatera mulai dari Barus sampai Inderapura.

Sumatera Barat terletak di pesisir barat bagian tengah pulau Sumatera yang terdiri dari dataran rendah di pantai barat dan dataran tinggi vulkanik yang dibentuk oleh Bukit Barisan. Provinsi ini memiliki daratan seluas $42.297,30 \mathrm{~km}^{2}$ yang setara dengan 2,17\% luas Indonesia. Dari luas tersebut, lebih dari 45,17\% merupakan kawasan yang masih ditutupi hutan lindung. Garis pantai provinsi ini seluruhnya bersentuhan dengan Samudera Hindia sepanjang $2.420 .357 \mathrm{~km}$ dengan luas perairan laut $186.580 \mathrm{~km}^{2}$. Kepulauan Mentawai yang dikelilingi oleh Samudera Hindia termasuk dalam provinsi ini (SKPT Mentawai, 2021)

Pada tanggal 30 September 2009, gempa yang berkekuatan 7.6 mengguncang Propinsi Sumatera Barat. Kerusakan yang terjadi akibat gempa ini tersebar di 13 dari 19 kabupaten/kota dan memakan korban jiwa lebih dari 1.100 orang. Daerah yang terkena dampak paling parah adalah Kota Padang, Kota Pariaman serta Kab. Padang Pariaman. Data historis yang mencatat kegiatan seismik selama 200 tahun kebelakang memperlihatkan bahwa Sumatera Barat sangat rawan terhadap gempa, berkaitan dengan lokasinya yang terletak pada zona pertemuan dari empat lempengan tektonik yang besar. Struktur geologi daerah ditambah dengan pemukiman penduduk yang padat di zona amplifikasi gempa yang lebih tinggi membantu menjelaskan kerusakan besar akibat gempa bumi, terutama daerah dekat pusat gempa diperlukan perhatian sehingga meminimalisir dampaknya, karena kesiapsiagaan mengantisipasi gempa selama ini belum memiliki roadmap yang sistematis (Novianti et al., 2017). Prediksi bencana gempa yang mungkin terjadi kembali dapat menjadi indikator penanggulangan bencana alam dimasa akan datang. Pengolahan data bencana alam dapat dilakukan menggunakan data mining (Ramadhan \& Prihandoko, 2017). Tujuan data mining mencari pola dalam database besar untuk pengambilan keputusan yang dapat digunakan pada waktu akan datang (Pramesti et al., 2017).

Provinsi Sumatera Barat berada di antara pertemuan dua lempeng benua besar (lempeng eurasia dan lempeng Indo-Australia) dan patahan (Sesar) Semangko. Di dekat 
pertemuan lempeng terdapat patahan Mentawai. Ketiganya merupakan daerah seismik aktif. Menurut catatan ahli gempa wilayah Sumatera Barat memiliki siklus 200 tahunan gempa besar yang pada awal abad ke-21 telah memasuki masa berulangnya siklus.

Teknik klustering data mining dapat digunakan untuk mengelompokan data dampak gempa bumi menjadi beberapa cluster berdasarkan kesamaan yang ada pada sekumpulan dataset. Dengan clustering dapat diketahui tingkat kerusakan untuk mengurangi resiko dampak kerusakan fasilitas umum, dampak sosial, dan ekonomi yang ditimbulkan dimana data langsung dikelompokan berdasarkan tingkat kemiripan kerusakannya (Artatia \& Hakim, 2015; Simamora et al., 2017). Metode yang digunakan dalam Data mining terdapat dua model yaitu prediktif dan deskriptif. Dalam metode prediktif, model biasanya dibuat dengan menggunakan datset yang hasilnya diketahi atau ber label. Sedangkan dalam metode deskriptif sebuah hubungan dapat di cari antara dua kumpulan data misalnya kerusakan besar dengan jumlah kejadian gempa yang berbeda dapat diselidiki untuk kesamaan.

Berdasarkan beberapa penelitian yang dilakukan bahwa k-means dan linier regressi dapat digunakan untuk mengelompokan atau mengklusterkan data pada kasus-kasus penambangan data baik dibidang terkait maupun bidang lainnya yang berhubungan dengan dataset yang beragam.

\section{Metode Penelitian}

\subsection{Metodologi Penelitian}

Metodologi penelitian yang digunakan pada eksperimen menggunakan model Knowledge Discovery in Database Data mining (KDD) adalah proses menggunakan metode data mining untuk mengekstrak apa yang dianggap sebagai pengetahuan (Azevedo \& Santos, 2008).

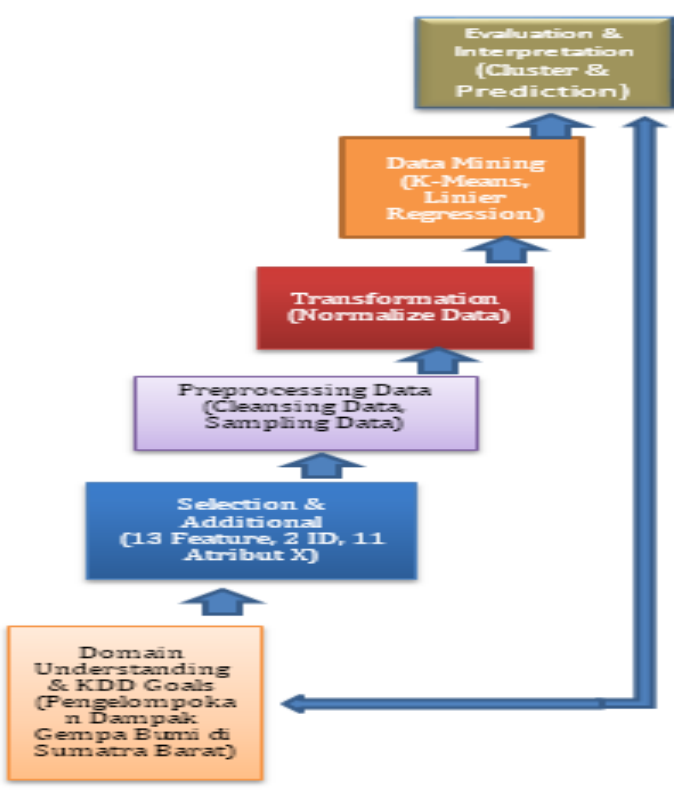

Sumber: Han dan Kamber (2006)

Gambar 1. Model KDD Modifikasi 
Penerapan proses Knowledge Discovery in databases (KDD) ini menggunakan langkah-langkah menurut (Han \& Kamber, 2006), gambar 1 merupakan blok diagram model langkah-langkah penelitian menggunakan metodologi $K D D$.

\subsection{Domain Understanding}

Langkah Ini adalah tahap pertama dari proses $K D D$ di mana tujuan didefinisikan dari sudut pandang pelanggan dan digunakan untuk mengembangkan dan memahami tentang domain aplikasi dan pengetahuan sebelumnya.

Pada tahap ini menentukan permasalahan penelitian yaitu tentang pengelompokan dampak gempa bumi pada tiap wilayah terdampak gempa bumi di Sumatera Barat dalam kurun waktu 2001 sampai dengan 2018 untuk mengetahui area dampak terbanyak dan area yang hanya memiliki dampak terkecil serta dampak lainnya disekitar wilayah terdampak gempa bumi.

\subsection{Selection Additional}

Langkah ini adalah tahap kedua proses $K D D$ yang berfokus menciptakan pada kumpulan data target dan subset sampel data atau variabel. Ini adalah tahap penting karena penemuan pengetahuan dilakukan pada semua ini.

Pada tahap ini menentukan atribut tentang dampak dari gempa bumi di Sumatra barat dan memilih atribut yang merupakan dampak dari gempa yang di ambil dari dataset gempa bumi di situs resmi BNPB (Badan Nasional Penanggulangan Bencana) lingkup area data local di Indonesia.

\subsection{Preprocessing Data}

Langkah Ini adalah tahap ketiga dari proses $K D D$ yang berfokus pada pembersihan data target dan pra-pemrosesan untuk menyelesaikan dan data yang konsisten tanpa noise dan inkonsistensi. Pada tahap ini strategi dikembangkan untuk menangani jenis bising dan data tidak konsisten.

Pada tahap ini pemilihan data yang sesuai dan memiliki keterikatan tentang dampak gempa dan pengambilan sampel data training dari kumpulan dataset pada portal BNPB di Indonesia.

\subsection{Transformation}

Langkah Ini adalah tahap keempat dari proses KDD yang berfokus pada transformasi data dari satu bentuk ke bentuk lainnya menjadi data algoritma penambangan dapat diimplementasikan dengan mudah. Untuk keperluan ini metode reduksi dan transformasi data berbeda diimplementasikan pada data target.

Tahap ini adalah proses penyederhanaan data untuk memudahkan pengolahan dalam penambangan data dan mereduksi dimensi data. Selanjutkan mempersiapkan dataset untuk proses pengolahan menggunakan algoritma penambangan data.

\subsection{Data mining}

Langkah Ini adalah tahap kelima dari proses $K D D$ di mana tugas penambangan data yang tepat dipilih berdasarkan tujuan tertentu yang ada didefinisikan pada tahap pertama. 
Contoh metode atau tugas penambangan data adalah klasifikasi, pengelompokan, regresi dan peringkasan lain-lain.

Tahap ini adalah proses pembuatan model dengan algoritma datamining untuk mengelompokan data gempa menjadi beberapa bagian berdasarkan dampak gempa.

\subsection{Evaluation}

Langkah Ini adalah langkah keenam dari proses $K D D$ yang berfokus pada interpretasi dan evaluasi pola penambangan. Langkah ini mungkin terlibat dalam visualisasi pola yang diekstraksi. Pada tahap ini adalah membuat pola atau pattern hasil dari pengelompokan data dan kemudian menyimpulkan hasil dari dampak gempa untuk proses pengambilan kebijakan untuk mengevaluasi hasil temuan dari dataset BNPD mengenai gemba bumi di Suamtra Barat.

\section{Hasil dan Pembahasan}

\subsection{Domain Understanding}

Tahap ini merupakan lingkup permasalahan dan tujuan capaian dari pengolahan data dengan menggunakan metodologi Data mining KDD pada dataset gempa bumi di wilayah provinsi Sumatera Barat yaitu bagaiamana pola terbaik untuk mengelompokan wilayah dampak gempa pada provinsi Sumatera Barat dengan akurat sesuai pada intensitas gempa yang terjadi dan dampak dari gempa tersebut terhadap beberapa kerugian seperti korban jiwa, kerusakan fasilitas public dan kerusahan unit hunian disekitar wilayah terdampak untuk diketahui sebagai hasil visualisasi untuk pengambilan keputusan terhadap pihak berwenang untuk di kemudian hari sebagai bahan evaluasi penanggulangan dampak bencana.

\subsection{Data Selection}

Penelitian ini menggunakan sumber dataset dari situs resmi BNPB di Indonesia. Dataset yang diolah diambil dari kejadian tahun 2001 - 2018 dengan 13 atribut terdiri dari tahun, wilayah, korban jiwa, kerusakan unit dan kerusakan fasilitas umum sebanyak 57 rows data 13 features. Berikut ini atribut yang akan digunakan dalam penelitian, yaitu:

Tabel 1. Input Atribut Prediktor Dampak Gempa Bumi

\begin{tabular}{|c|c|c|}
\hline Keterangan & Variabel & Kode \\
\hline \multirow{13}{*}{ INPUT } & Tahun & $\mathrm{X} 1$ \\
\hline & Wilayah & $x 2$ \\
\hline & Korban Meninggal \& Hilang & X3 \\
\hline & Korban Luka-luka & X4 \\
\hline & Korban Menderita \& mengungsi & $\times 5$ \\
\hline & Kerusakan Unit Berat & $\mathrm{X} 6$ \\
\hline & Kerusakan Unit Sedang & X7 \\
\hline & Kerusakan Unit Ringan & X8 \\
\hline & Terendam & X9 \\
\hline & Kerusakan Fas. Kesehatan & $\mathrm{X} 10$ \\
\hline & Kerusakan Fas. Ibadah & $\mathrm{X} 11$ \\
\hline & Kerusakan Fas. Pendidikan & $\mathrm{X} 12$ \\
\hline & Jumlah Kejadian Per-tahun & $\mathrm{X} 13$ \\
\hline
\end{tabular}

Sumber: Hasil Penelitian (2021)

\subsection{Preprocessing Data}

Tahap ini adalah pembersihan data dari data yang inkonsistensi dengan memilih fitur atibut yang memiliki hubungan terhadap gempa bumi dan pengambilan sampel data dari 57 
rows data menjadi 50 rows data. Berikut hasil preprocessing data pada dataset gempa bumi BNPS periode tahun 2001-2018.

Tabel 2. Sampel Dataset Gempa Sumatera Barat

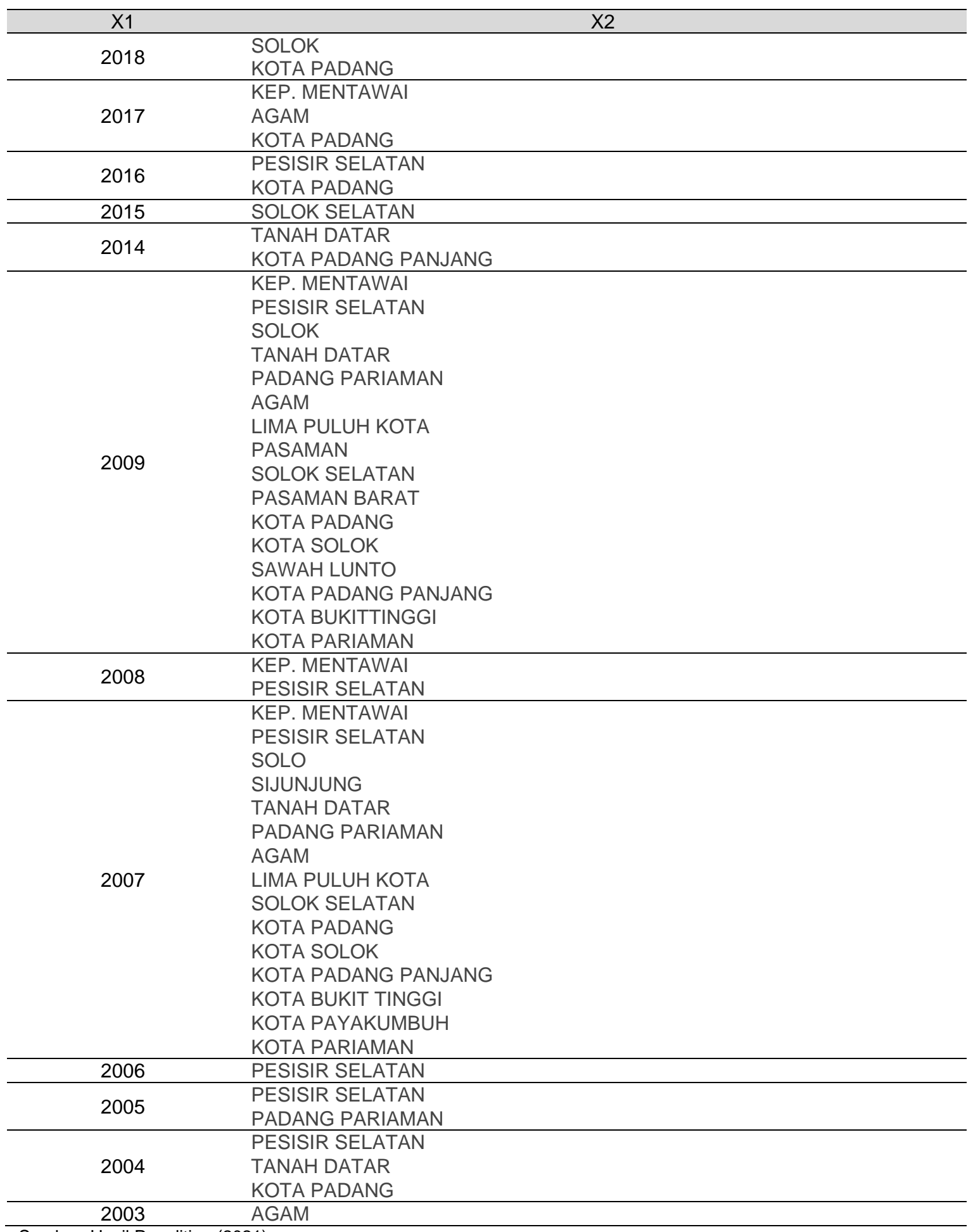

Sumber: Hasil Penelitian (2021)

\subsection{Transformasi Data}

Sebelum dilakukan pelatihan pada dataset, data primer dinormalisasikan dahulu dengan untuk penyederhanaan data dan dapat diimplementasi untuk melakukan pelatihan. 
Tabel 3. Sampel Hasil Transformasi Data

\begin{tabular}{|c|c|c|c|c|}
\hline No & $\mathrm{X} 3$ & $\mathrm{X} 4$ & $\times 5$ & $\mathrm{X} 6$ \\
\hline 1 & -0.2295 & -0.2597 & -0.2799 & -0.2951 \\
\hline 2 & -0.2388 & -0.3037 & -0.2849 & -0.2965 \\
\hline 3 & -0.2388 & -0.3037 & -0.2849 & -0.297 \\
\hline 4 & -0.2388 & -0.3037 & -0.2849 & -0.2971 \\
\hline 5 & -0.2388 & -0.2982 & -0.2849 & -0.2971 \\
\hline 6 & -0.2388 & -0.1883 & -0.2757 & -0.2865 \\
\hline 7 & -0.2295 & -0.2927 & -0.2849 & -0.2971 \\
\hline 8 & -0.2388 & -0.3037 & -0.2849 & -0.2971 \\
\hline 9 & -0.2388 & -0.2927 & -0.2849 & -0.2971 \\
\hline 10 & -0.2388 & -0.2927 & -0.2849 & -0.2971 \\
\hline 11 & -0.2388 & -0.3037 & -0.2849 & -0.295 \\
\hline 12 & -0.1552 & -0.1554 & -0.2849 & -0.0717 \\
\hline 13 & -0.2388 & -0.2762 & -0.2849 & -0.2822 \\
\hline 14 & -0.2388 & -0.3037 & -0.2849 & -0.2941 \\
\hline 15 & 5.9439 & -0.1663 & -0.2849 & 5.658 \\
\hline 16 & 0.5132 & 0.4489 & 0.3212 & 0.8546 \\
\hline 17 & -0.2388 & -0.3037 & -0.2849 & -0.2971 \\
\hline 18 & -0.2388 & -0.3037 & -0.2849 & -0.2795 \\
\hline 19 & -0.2388 & -0.3037 & -0.2849 & -0.2971 \\
\hline 20 & -0.1923 & -0.1389 & -0.2849 & 0.0369 \\
\hline 21 & 3.3353 & 6.3765 & -0.2849 & 3.5774 \\
\hline 22 & -0.2109 & -0.3037 & -0.2849 & -0.2971 \\
\hline 23 & -0.2388 & -0.3037 & -0.2849 & -0.2971 \\
\hline 24 & -0.2388 & -0.1938 & -0.2849 & -0.2953 \\
\hline 25 & -0.2388 & -0.3037 & -0.2849 & -0.2971 \\
\hline 26 & 0.2068 & 1.6301 & -0.2849 & 0.392 \\
\hline 27 & -0.2202 & -0.2927 & -0.2387 & -0.2783 \\
\hline 28 & -0.2388 & -0.3037 & -0.2849 & -0.2971 \\
\hline 29 & -0.2109 & -0.1444 & -0.2849 & -0.0246 \\
\hline 30 & -0.2016 & -0.2982 & -0.2849 & 0.073 \\
\hline 31 & -0.0717 & 1.0532 & 0.7485 & -0.2054 \\
\hline 32 & -0.2388 & -0.3037 & -0.2849 & -0.2971 \\
\hline 33 & -0.1366 & 0.9763 & 5.8375 & 0.1756 \\
\hline 34 & -0.2109 & -0.2433 & 0.2284 & 0.3357 \\
\hline 35 & -0.0902 & 0.4984 & 2.5868 & -0.0206 \\
\hline 36 & -0.2295 & -0.2597 & -0.247 & -0.2923 \\
\hline 37 & -0.2388 & -0.3037 & -0.2849 & -0.2971 \\
\hline 38 & -0.2016 & -0.1828 & -0.2849 & -0.0991 \\
\hline 39 & -0.1738 & -0.1993 & -0.2849 & -0.2924 \\
\hline 40 & -0.2202 & -0.029 & 2.0531 & -0.2242 \\
\hline 41 & -0.1738 & 0.2457 & -0.1439 & -0.2961 \\
\hline 42 & -0.2295 & -0.2268 & -0.2822 & -0.2893 \\
\hline 43 & -0.2388 & -0.3037 & -0.2849 & -0.2911 \\
\hline 44 & -0.2388 & -0.3037 & -0.2849 & -0.2971 \\
\hline 45 & -0.2388 & -0.3037 & -0.2849 & -0.2971 \\
\hline 46 & -0.2295 & -0.3037 & -0.2849 & -0.2107 \\
\hline 47 & -0.2295 & -0.2542 & -0.2849 & -0.2942 \\
\hline 48 & -0.1831 & -0.1663 & 0.0221 & -0.2557 \\
\hline 49 & -0.2388 & -0.3037 & -0.2849 & -0.2971 \\
\hline 50 & -0.2388 & -0.3037 & -0.0722 & -0.2859 \\
\hline
\end{tabular}

Sumber: Hasil Penelitian (2021)

\subsection{Data Mining}

Tahap ini dibuatkan model pengolahan dengan metode $K D D$ yang sudah di modifikasi menggunakan tools Rapidminer dengan membuat model klustering algoritma kmeans dan Linear Regression. Gambar 2 menjelaskan model pengolahan clustering dengan algoritma $K$ Means menggunakan tools Rapidminer. 


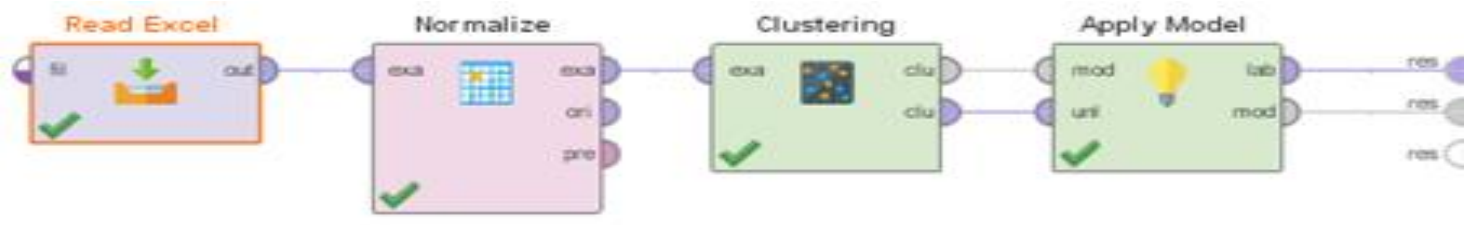

Sumber: Hasil Penelitian (2021)

Gambar 2. Model pengolahan clustering dengan algoritma K-Means.

Sedangkan pada gambar 3 menjelaskan model pengolahan regresi dengan algoritma linear regression menggunakan tools Rapidminer.

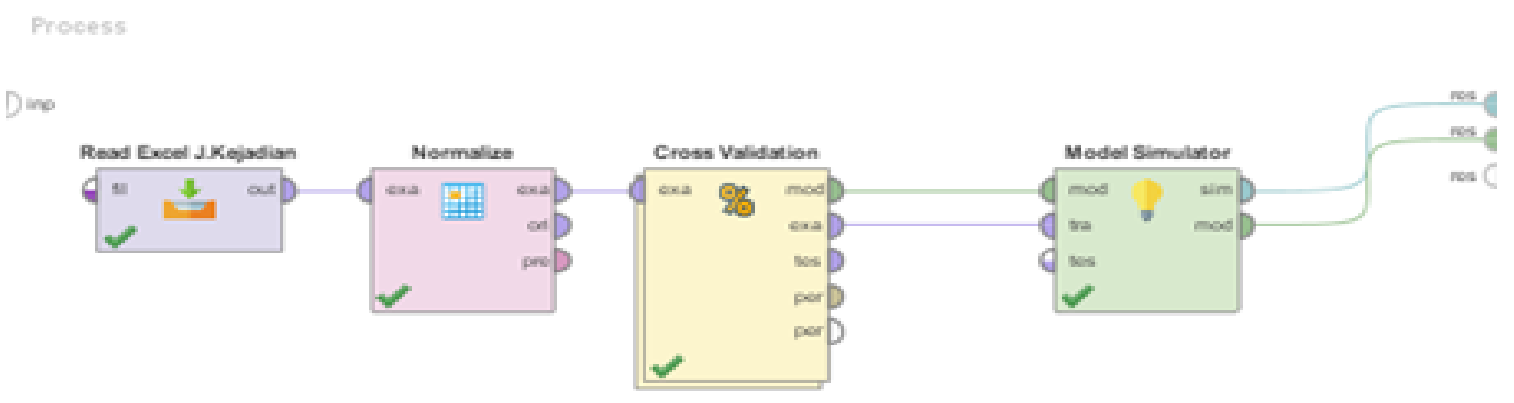

Sumber: Hasil Penelitian (2021)

Gambar 3. Model Pengolahan Regresi Dengan Algoritma Linear Regression

\subsection{Evaluasi}

Tahap ini merupakan hasil dari pengolahan pada proses kluster untuk mengetahui pengelompokan penyebaran wilayah dampak kerusakan gempa sesuai dengan intensitas kerusakan pada provinsi Sumatra Barat, tabel 4 adalah hasil penyajian dari data yang sudah di olah.

Tabel 4. Data Hasil Kluster

\begin{tabular}{|c|c|c|}
\hline Th & Wilayah & Hasil Cluster \\
\hline 2018 & SOLOK & cluster_0 \\
\hline 2018 & KOTA PADANG & cluster 0 \\
\hline 2017 & KEP. MENTAWAI & cluster_0 \\
\hline 2017 & AGAM & cluster 0 \\
\hline 2017 & KOTA PADANG & cluster 0 \\
\hline 2016 & PESISIR SELATAN & cluster_0 \\
\hline 2016 & KOTA PADANG & cluster_0 \\
\hline 2015 & SOLOK SELATAN & cluster 0 \\
\hline 2014 & TANAH DATAR & cluster_0 \\
\hline 2014 & KOTA PADANG PANJANG & cluster_0 \\
\hline 2013 & TIDAK ADA & cluster 0 \\
\hline 2012 & TIDAK ADA & cluster_0 \\
\hline 2011 & TIDAK ADA & cluster_0 \\
\hline 2010 & TIDAK ADA & cluster_0 \\
\hline 2009 & KEP. MENTAWAI & cluster_0 \\
\hline 2009 & PESISIR SELATAN & cluster_0 \\
\hline 2009 & SOLOK & cluster 0 \\
\hline 2009 & TANAH DATAR & cluster_0 \\
\hline 2009 & PADANG PARIAMAN & cluster_2 \\
\hline 2009 & AGAM & cluster_0 \\
\hline 2009 & LIMA PULUH KOTA & cluster_0 \\
\hline 2009 & PASAMAN & cluster_0 \\
\hline 2009 & SOLOK SELATAN & cluster 0 \\
\hline
\end{tabular}




\begin{tabular}{|c|c|c|}
\hline Th & Wilayah & Hasil Cluster \\
\hline 2009 & PASAMAN BARAT & cluster 0 \\
\hline 2009 & KOTA PADANG & cluster 1 \\
\hline 2009 & KOTA SOLOK & cluster_0 \\
\hline 2009 & SAWAH LUNTO & cluster_0 \\
\hline 2009 & KOTA PADANG PANJANG & cluster 0 \\
\hline 2009 & KOTA BUKITTINGGI & cluster_0 \\
\hline 2009 & KOTA PARIAMAN & cluster_0 \\
\hline 2008 & KEP. MENTAWAI & cluster 0 \\
\hline 2008 & PESISIR SELATAN & cluster_0 \\
\hline 2007 & KEP. MENTAWAI & cluster_0 \\
\hline 2007 & PESISIR SELATAN & cluster_0 \\
\hline 2007 & SOLO & cluster 0 \\
\hline 2007 & SIJUNJUNG & cluster_0 \\
\hline 2007 & TANAH DATAR & cluster_0 \\
\hline 2007 & PADANG PARIAMAN & cluster 0 \\
\hline 2007 & AGAM & cluster_0 \\
\hline 2007 & LIMA PULUH KOTA & cluster_0 \\
\hline 2007 & SOLOK SELATAN & cluster_0 \\
\hline 2007 & KOTA PADANG & cluster 0 \\
\hline 2007 & KOTA SOLOK & cluster_0 \\
\hline 2007 & KOTA PADANG PANJANG & cluster_0 \\
\hline 2007 & KOTA BUKIT TINGGI & cluster_0 \\
\hline 2007 & KOTA PAYAKUMBUH & cluster_0 \\
\hline 2007 & KOTA PARIAMAN & cluster 0 \\
\hline 2006 & PESISIR SELATAN & cluster_0 \\
\hline 2005 & PESISIR SELATAN & cluster_0 \\
\hline 2005 & PADANG PARIAMAN & cluster_0 \\
\hline 2004 & PESISIR SELATAN & cluster 0 \\
\hline 2004 & TANAH DATAR & cluster_0 \\
\hline 2004 & KOTA PADANG & cluster_0 \\
\hline 2003 & AGAM & cluster_0 \\
\hline 2002 & TIDAK ADA & cluster_0 \\
\hline 2001 & TIDAK ADA & cluster_0 \\
\hline
\end{tabular}

Sumber: Hasil Penelitian (2021)

Tabel 5. Hasil Prediksi Gempa Per-Wilayah di Sumatera Barat

\begin{tabular}{clc}
\hline Tahun & wilayah & Prediction \\
\hline 2018 & SOLOK & 1.725 \\
\hline 2018 & KOTA PADANG & 1.959 \\
\hline 2017 & KEP. MENTAWAI & 1.92 \\
\hline 2017 & AGAM & 1.976 \\
\hline 2017 & KOTA PADANG & 1.975 \\
\hline 2016 & PESISIR SELATAN & 1.91 \\
\hline 2016 & KOTA PADANG & 1.92 \\
\hline 2015 & SOLOK SELATAN & 0.131 \\
\hline 2014 & TANAH DATAR & 2.488 \\
\hline 2014 & KOTA PADANG PANJANG & 2.039 \\
\hline 2009 & KEP. MENTAWAI & 44.094 \\
\hline 2009 & PESISIR SELATAN & 4.629 \\
\hline 2009 & SOLOK & 3.046 \\
\hline 2009 & TANAH DATAR & 47.96 \\
\hline 2009 & PADANG PARIAMAN & 40.694 \\
\hline 2009 & AGAM & 1.92 \\
\hline 2009 & LIMA PULUH KOTA & 5.323 \\
\hline 2009 & PASAMAN & 1.92 \\
\hline 2009 & SOLOK SELATAN & 19.895 \\
\hline 2009 & PASAMAN BARAT & \\
\hline
\end{tabular}




\begin{tabular}{|c|c|c|}
\hline Tahun & wilayah & Prediction \\
\hline 2009 & KOTA PADANG & 184.535 \\
\hline 2009 & KOTA SOLOK & 1.855 \\
\hline 2009 & SAWAH LUNTO & 1.92 \\
\hline 2009 & KOTA PADANG PANJANG & 5.073 \\
\hline 2009 & KOTA BUKITTINGGI & 1.905 \\
\hline 2009 & KOTA PARIAMAN & 41.262 \\
\hline 2008 & KEP. MENTAWAI & 2.27 \\
\hline 2008 & PESISIR SELATAN & 1.924 \\
\hline 2007 & KEP. MENTAWAI & 13.593 \\
\hline 2007 & PESISIR SELATAN & 30.73 \\
\hline 2007 & SOLO & 20.679 \\
\hline 2007 & SIJUNJUNG & 1.997 \\
\hline 2007 & TANAH DATAR & 50.474 \\
\hline 2007 & PADANG PARIAMAN & 46.123 \\
\hline 2007 & AGAM & 21.231 \\
\hline 2007 & LIMA PULUH KOTA & 2.951 \\
\hline 2007 & SOLOK SELATAN & 2.01 \\
\hline 2007 & KOTA PADANG & 32.166 \\
\hline 2007 & KOTA SOLOK & 3.114 \\
\hline 2007 & KOTA PADANG PANJANG & 11.354 \\
\hline 2007 & KOTA BUKIT TINGGI & 6.691 \\
\hline 2007 & KOTA PAYAKUMBUH & 3.449 \\
\hline 2007 & KOTA PARIAMAN & 2.616 \\
\hline 2006 & PESISIR SELATAN & 1.92 \\
\hline 2005 & PESISIR SELATAN & 2.02 \\
\hline 2005 & PADANG PARIAMAN & 9.998 \\
\hline 2004 & PESISIR SELATAN & 2.713 \\
\hline 2004 & TANAH DATAR & 4.807 \\
\hline 2004 & KOTA PADANG & 2.124 \\
\hline 2003 & AGAM & 1.92 \\
\hline
\end{tabular}

Sumber: Hasil Penelitian (2021)

Gambar 4 merupakan hasil visualisasi dari intensitas dampak gempa di provinsi Sumatera Barat, berdasarkan pengolahan data dengan algoritma $K$-Means dan algoritma linear regression menggunakan tools Rapidminer.

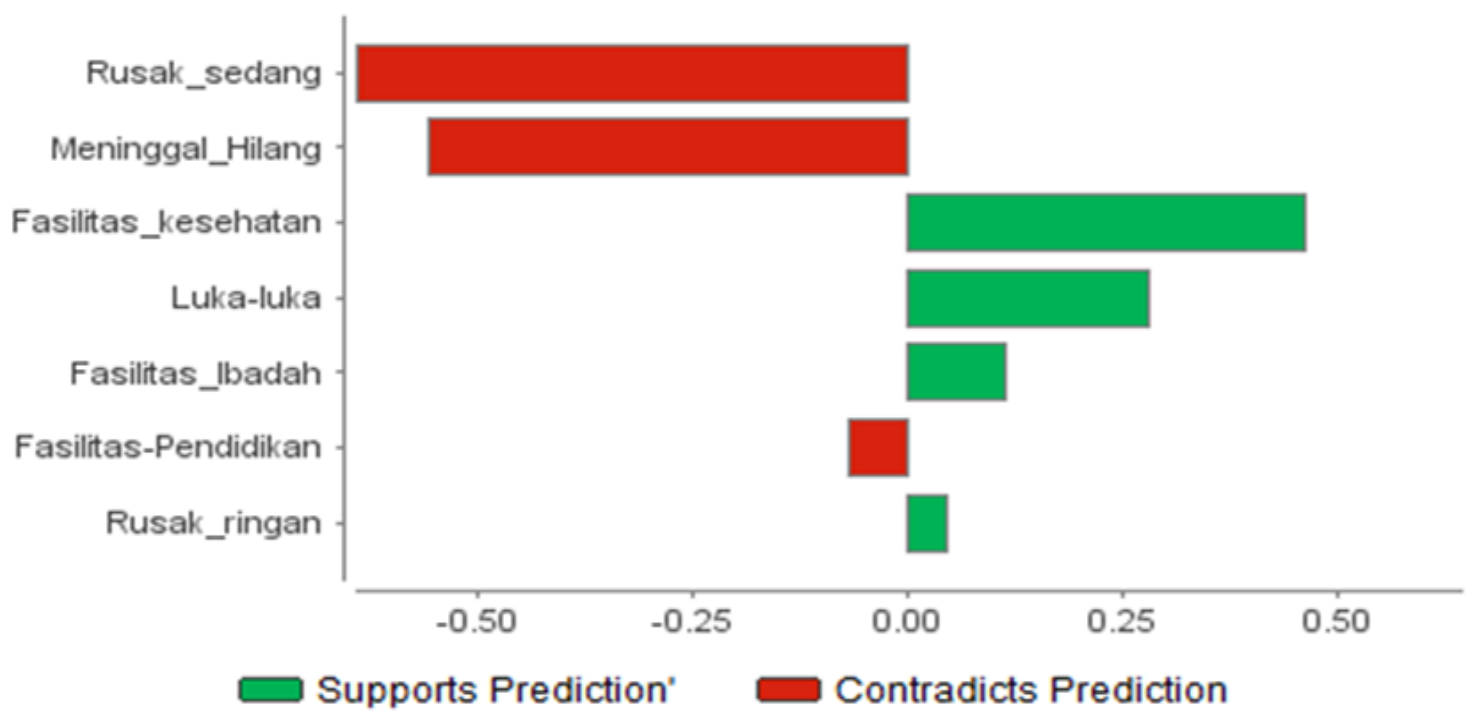

Sumber: Hasil Penelitian (2021)

Gambar 4. Hasil Visualisasi Intensitas Dampak Gempa di Provinsi Sumatera Barat. 


\section{Kesimpulan}

Penelitian ini telah melakukan pengujian model menggunakan algoritma Clustering $\mathrm{K}$ Means dan algoritma pridiksi menggunakan Linier Regression untuk mengolah dataset gempa mengelompokan dan memprediksi dampak gempa menjadi beberapa kelompok dan memprediksi dampak gempa terbanyak di wilayah Sumatra Barat. Hasil penelitian ini membuktikan penggunaan algoritma clustering K-means mampu mengelompokan wilayah gempa dengan dampak bervariatif menjadi 3 kluster dimana kluster ke-1 adalah dampak gempa terbanyak, kluster ke-2 dampak gempa sedang dan kluster ke-3 dampak gempa ringan. Dari kluster tersebut dampak terbesar untuk korban dan kerusakan unit permukiman dan kerusakan fasilitas umum terpusat pada kluster ke-1 yaitu di kota padang pada tahun 2009 untuk wilayah Sumatra Barat, serta hasil dari prediksi didapatkan dampak yang paling dominan adalah dampak kerusakan fasilitas kesehatan, korban jiwa luka-luka, dampak kerusakan fasilitas ibadah, dampak kerusakan unit permukiman ringan. Adapun model yang telah terbentuk selanjutnya dapat dikembangkan dan diimplementasikan ke dalam sebuah visualisasi lokasi terdampak gempa di wilayah Sumatera Barat. Sehingga dapat membantu dan memudahkan bagi para pemegang kewenangan dalam mengambil sebuah keputusan untuk menanggulangi dampak bencana alam khususnya gempa bumi dalam penangan bantuan dan revitalisasi fasilitas publik serta permukiman secara merata, cepat dan akurat sesuai intensitas dampak kerusakan yang terjadi.

\section{Daftar Pustaka}

Artatia, H., \& Hakim, R. F. (2015). Pengelompokan Dampak Gempa Bumi dari Segi Kerusakan Fasilitas pada Provinsi yang Berpotensi Gempa di Indonesia Menggunakan K-MeansClustering. Prosiding Seminar Nasional Matematika Dan Pendidikan Matematika UMS, 742-748.

Azevedo, A., \& Santos, M. F. (2008). Kdd, Semma And Crisp-Dm : A Parallel Overview.

Davies, P. B. (2004). Database Systems Third Edition. Palgrave Macmillan.

Han, J., \& Kamber, M. (2006). Data Mining Concepts and Techniques Second Edition.

Novianti, P., Setyorini, D., \& Rafflesia, U. (2017). K-Means Cluster Analysis in Earthquake Epicenter Clustering. International Journal of Advances in Intelligent Informatics, 3(2), 8189. https://doi.org/10.26555/ijain.v3i2.100

Pramesti, D. F., Lahan, Tanzil Furqon, M., \& Dewi, C. (2017). Implementasi Metode K-Medoids Clustering Untuk Pengelompokan Data Potensi Kebakaran Hutan/Lahan Berdasarkan Persebaran Titik Panas (Hotspot). Jurnal Pengembangan Teknologi Informasi Dan IImu Komputer, 1(9), 723-732. https://doi.org/10.1109/EUMC.2008.4751704

Pramudiono. (2006). Apa Itu Data Mining. ANDI.

Ramadhan, M. I., \& Prihandoko. (2017). Penerapan Data Mining untuk Analisis Data Bencana Milik BNPB Menggunakan Algoritma K-Means dan Linear Regression. Jurnal Informatika Dan Komputer, 22(1), 57-65. 
Simamora, D. A. S., Furqon, M. T., \& Priyambadha, B. (2017). Clustering Data Kejadian Tsunami Yang Disebabkan Oleh Gempa Bumi Dengan Menggunakan Algoritma KMedoids. Jurnal Pengembangan Teknologi Informasi Dan IImu Komputer, 1(8), 635-640.

SKPT Mentawai. (2021). Kondisi Geografis Kabupaten Kepulauan Mentawai. Kementrian Kelautan Dan Perikanan. https://kkp.go.id/SKPT/Mentawai/page/1133-skpt-kabupatenkepulauan-mentawai 